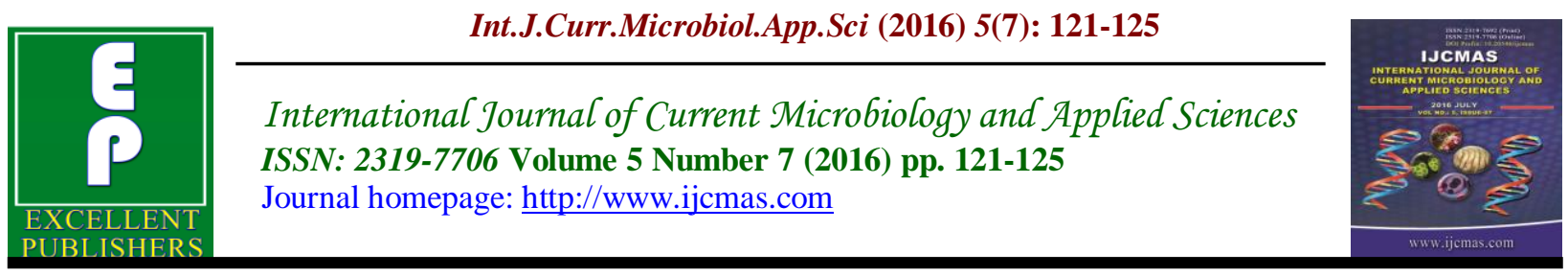

Original Research Article

http://dx.doi.org/10.20546/ijcmas.2016.507.010

\title{
Application of Flyash for the Removal of Toxic Metals from Wastewaters through Biosorption
}

\author{
Ahmad Ashfaq* and Mohd Kaifiyan \\ Civil Engineering Section, Faculty of Engineering \& Technology, Aligarh Muslim University, \\ A.M.U., Aligarh, India \\ *Corresponding author
}

\begin{abstract}
A B S T R A C T
Keywords

Adsorption,

Adsorbent,

Environment,

Flyash,

Heavy metal.

Article Info

Accepted:

12 June 2016

Available Online:

10 July 2016

Environmental pollution by heavy metal is arising as the most endangering tasks to both water sources and atmosphere quality. The treatment of heavy metals is of special concern due to their recalcitrance and persistence in the environment. The flyash was used in this work as low cost sorbent material for removal of $\mathrm{Pb}$ (II) and $\mathrm{Fe}$ (II) ions from aqueous solutions. The samples of adsorbent were sorted according to the particles diameter by standard sieves 250-500 $\mu \mathrm{m}$. Batch experiments were carried out to study the sorption process and several parameters such as Initial $\mathrm{pH}$ of adsorbent, effect of contact time, effect of adsorbent amount and effect of metal concentration were conducted in these experiments. The effects of any one of those previously mentioned parameters on the sorption capacity were studied while the other parameters were kept constant. It was found that the obtained maximum sorption capacities of flyash for the removal of selected heavy metals were very high. This provide us to use flyash as a low cost material to clean up the water from toxic heavy metals studied.
\end{abstract}

\section{Introduction}

The presence of heavy metals in industrial wastewater has posed many serious environmental problems due to their nonbiodegradable properties and toxicity, even at low concentrations (Vilar, et al., 2007) which directly produce detrimental and toxicological impact on the biotic resources. The heavy metal ions are not only toxic to living organisms in water, but also cause harmful effects to land animals including humans through food chain transfers. In living organisms, heavy metal ions can particularly bind to nucleic acids, proteins, and small metabolites (Liu, et al., 2008).
Therefore, it is necessary to eliminate such hazardous heavy metal ion in wastewater before discharging it into the ecosystem. The metals which are required to remove from the aquatic environment and need immediate concern are $\mathrm{Zn}^{2+}, \mathrm{Cu}^{2+}, \mathrm{Ni}^{2+}$, $\mathrm{Cd}^{2+}, \mathrm{Pb}^{2+}$, and $\mathrm{Cr}^{6+}$ (Moradi, et al., 2010; Al-Degs, et al., 2006; Molinari et al., 2004; Moradi and Zare, 2011). These toxic metal ions commonly exist in process waste streams from mining operations, metal plating facilities, power generation facilities, electronic device manufacturing units, and tanneries. Because of economic and 
environmental factors, the removal and recovery of heavy-metal ions from industrial wastewater have been a significant concern in most industrial branches (Ngomsik, et al., 2009; Yin, et al., 2010). Different technologies have been used for the removal of heavy metals from wastewater. They mainly include: precipitation, ion exchange, membrane processes, evaporation, chemical oxidation or reduction, solvent extraction and biological materials. These techniques are very expensive and economically unfavorable or technically complicated, and are used only in special cases of wastewater treatment (Abdel-Halim, et al 2003, Qadeer et al., 2005). Relatively a new green technology for the treatment of industrial wastewater is adsorption of heavy metals and dyes from aqueous solutions by using natural material. Adsorption process has been proved to be an excellent way to treat industrial waste effluents, offering significant advantages like the low cost, availability, profitability, easy operation, and efficiency (Amuda, et al., 2007; Guptaa, et al., 2006; Shin, et al., 2005). In this study, flyash as an adsorbent was investigated for the removal of metals ions from aqueous solution under competitive adsorption conditions. The effects of initial $\mathrm{pH}$, contact time, initial ion concentration on adsorption of those ions were studied. Flyash was found to be an effective adsorbent for heavy metals and it performed well in the presence of competing ions.

\section{Material and Methods}

\section{Preparation of Binary Metal Mixtures}

The applicability of the empirical Freundlich model to the biosorption of $\mathrm{Pb}$ (II) and $\mathrm{Fe}(\mathrm{II})$ ions from the binary metal mixtures by flyash was checked for different sets of data. The initial concentrations of $\mathrm{Pb}$ (II) ions were varied between $10-80 \mathrm{mgL}^{-1}$, whereas the $\mathrm{Fe}$ (II) ion concentration in each metal mixture was held constant at 10, 20, 50, or $60 \& 80 \mathrm{mgL}^{-1}$.

\section{Biosorption Studies}

Experiments were conducted in $100 \mathrm{ml}$ flasks containing $50 \mathrm{ml}$ of heavy metal solutions and $0.5 \mathrm{~g}$ of biomass. The $\mathrm{pH}$ value was selected based on reported results indicating that high sorption of copper ions is attained for $\mathrm{pH}$ between 4 and 6 The $\mathrm{pH}$ range chosen for the sorption is also based on avoiding metal precipitation and was adjusted to the required value with 0.1 $\mathrm{mol} / \mathrm{L} \mathrm{HNO} 3$ or $0.1 \mathrm{~mol} / \mathrm{L} \mathrm{NaOH}$ hourly, throughout the experiment. The mixtures were shaken on a rotary shaker (agitation rate, $200 \mathrm{rpm}$ ) for 2.5 hours, and then set still 1 hour to reach equilibrium. Then the biosorbent was filtered through an acidcleaned $0.45 \mu \mathrm{m}$ Millipore filter and the concentrations of heavy metal ions in the filtrates were analyzed by flame atomic absorption spectrometer (Model GBC 932 Plus Australia). Each experiment was repeated twice. For the kinetic experiments, 25-200 mg of biomass was contacted with $50 \mathrm{ml}$ of the metal ion solutions of initial concentration between 10-100 mg/l, keeping the same conditions as described above. At scheduled time intervals, $8 \mathrm{ml}$ solution samples were drawn out and the concentrations of the residual heavy metals were analyzed. The depleted metal solutions were then analyzed to assess the metal concentration decline. Equilibrium isotherms were obtained using sample doses of $0.5 \mathrm{~g} / 50 \mathrm{ml}$ solution and a range of initial metal concentrations between 10 and 100 $\mathrm{mg} / \mathrm{l}$. The general procedure depicted above was followed, applying the same experimental conditions. The suspensions were stirred for the time required to attain equilibrium, as determined from kinetic measurements. Duplicate experiments were 
carried out for all the experiments. Average values are reported. In all the tests, metal and sorbent free blanks were also used for control.

\section{Results and Discussion}

\section{Biosorption of $\mathrm{Pb}$ (II) and $\mathrm{Fe}(\mathrm{II})$ in binary components of solution}

In order to determine the effects of initial $\mathrm{Pb}$ (II) and $\mathrm{Fe}$ (II) ion concentrations on the equilibrium from binary metal solution, initial concentrations of $\mathrm{Pb}(\mathrm{II})$ were varied between 10 and $80 \mathrm{mg} / \mathrm{l}$, while the initial $\mathrm{Fe}(\mathrm{II})$ concentration, in each biosorption medium was held constant at 10, 20, 50, 60 $\mathrm{mg} / \mathrm{l}$ respectively at $\mathrm{pH}$ 5.2. The nonlinearzed biosorption isotherms of $\mathrm{Pb}$ (II) in the absence and in the presence of increasing concentrations of $\mathrm{Fe}$ (II) ions obtained are shown in Fig: 1. Equilibrium $\mathrm{Pb}$ (II) uptake increased 3.26-32.16 $\mathrm{mgg}^{-1}$ by increasing the initial $\mathrm{Pb}(\mathrm{II})$ concentration from 10 to $80 \mathrm{mg} / \mathrm{l}$. The curve-linear relationship between the amount of $\mathrm{Pb}$ (II) biosorbed per unit weight flyash and the residual concentration at equilibrium suggests that saturation occurred at higher concentrations of this metal ion. When the equilibrium uptakes of $\mathrm{Pb}$ (II) ions by biosorbent in the presence of ions are compared with the situation, where these ions are present singly, inhibition occurred in the equilibrium uptake of the same. The equilibrium uptake of $\mathrm{Fe}(\mathrm{II})$ decreased regularly (17.04-12.08 $\mathrm{mgg}^{-1}$ ) with increasing $\mathrm{Fe}(\mathrm{II})$ concentrations. This effect of ions on the equilibrium $\mathrm{Pb}$ (II) uptake was dominant at higher initial concentrations. At $60 \mathrm{mgl}^{-1}$ of initial $\mathrm{Pb}(\mathrm{II})$ concentration, in the absence and in the presence of $10 \mathrm{mgl}^{-1}$ of $\mathrm{Fe}$ (II) concentration, biosorbed $\mathrm{Pb}$ (II) quantities at equilibrium were found 48.48 $\mathrm{mgg}^{-1}$ and $32.16 \mathrm{mgg}^{-1}$ respectively. Although $\mathrm{Pb}$ (II) was biosorbed significantly the $\mathrm{Fe}(\mathrm{II})$ ions were also biosorbed by flyash as $5.36 \mathrm{mgg}^{-1}$ at $60 \mathrm{mgl}^{-1}$. This situation shows the competition between $\mathrm{Pb}$ (II) and $\mathrm{Fe}(\mathrm{II})$ ions, although the initial $\mathrm{pH}$ plays a significant role on selective biosorption. The presence of the other ion develops a competition for the biosorption sites on the surface while some sites are captured by the second metal ion.

Fig.1 The empirical Freundlich biosorption isotherms of $\mathrm{Pb}(\mathrm{II})[\mathrm{pH}: 5.2]$ in the presence of increasing concentrations of $\mathrm{Fe}(\mathrm{II})$.

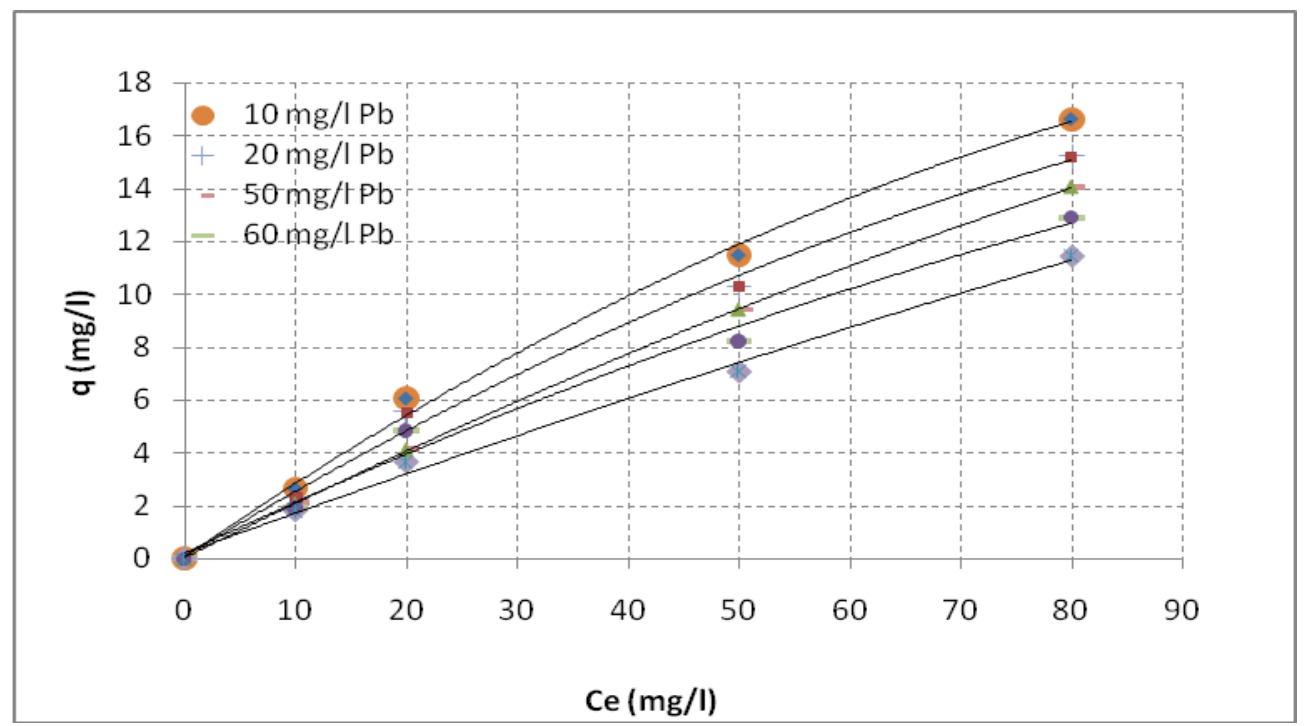




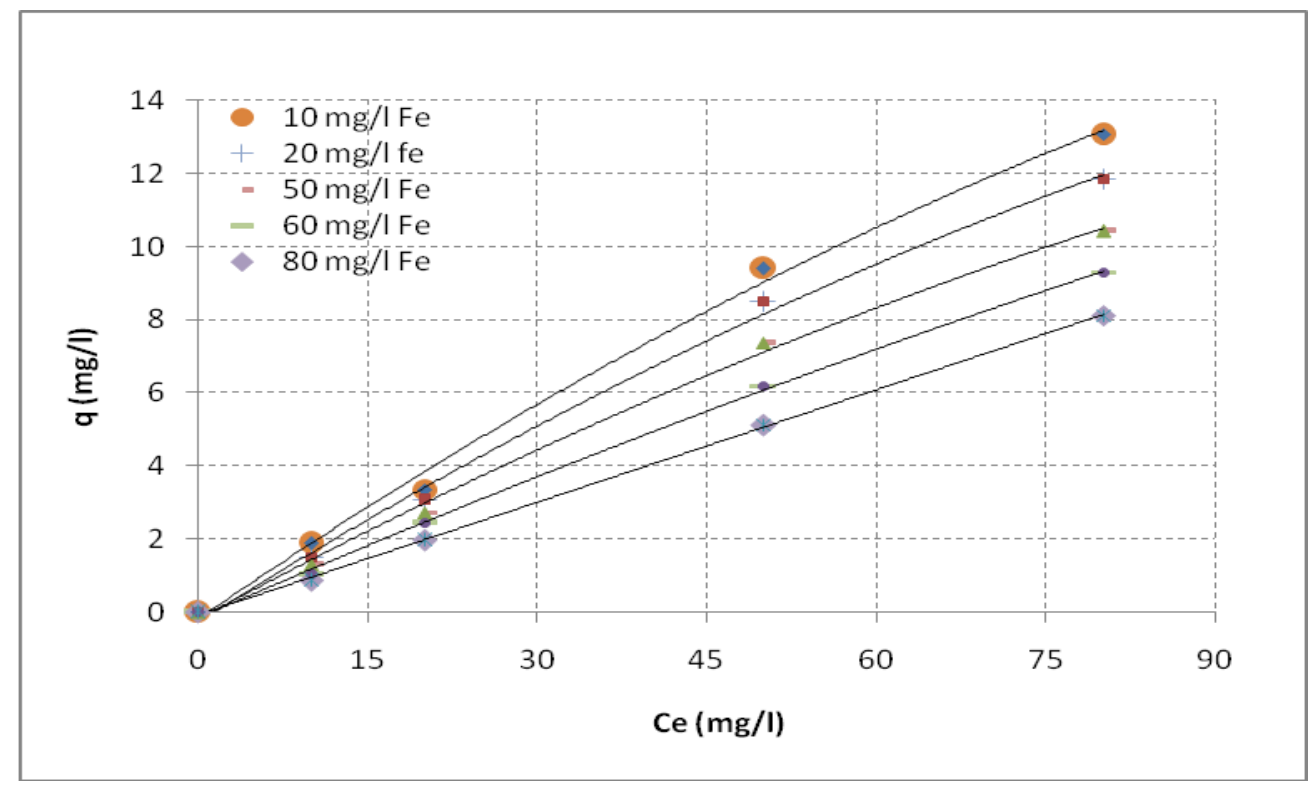

In conclusion, the present study proves the capability and effectiveness of flyash as an adsorbent for heavy metals removal. The adsorption process is a function of the adsorbent and adsorbate concentrations and contact time. Equilibrium was achieved practically in $2 \mathrm{~h}$. Adsorption behavior of $\mathrm{Pb}$ (II) and $\mathrm{Fe}$ (II) were affected by experimental parameters such as $\mathrm{pH}$, contact time, and initial concentration of ions solution. It was found that adsorption isotherms were better described by Freundlich biosorption isotherms model for all of those metal ions. The maximum adsorption capacity values of $\mathrm{Pb}$ (II) and $\mathrm{Fe}(\mathrm{II})$ ions in a mixture of binary metal ions with flyash estimated 78.5 and $80.0 \mathrm{mg} / \mathrm{g}$, respectively.

\section{Acknowledgement}

This research was financially supported by the Council of Science \& Technology, Uttar Pradesh (C.S.T. U.P, Lucknow) with Project Gant No: C.S.T. / D.1440.

\section{References}

Abdel-Halim, S.H., A.M.A. Shehata, ElShahat, M.F. 2003. Removal of Lead
Ion from Industrial Wastewater by Different Types of Natural Materials. Water Res., 37: 1678-1683.

Al-Degs, Y.S., M.I. El-Barghouthi, A.A. Issa, M.A. Khraisheh, Walker, G.M. 2006. Sorption of $\mathrm{Zn}$ (II), Pb (II), and Co (II) using natural sorbents: equilibrium and kinetic studies. Water Res., 40(14): 2645-2658.

Amuda, O.S., A.A. Giwa, Bello, I.A. 2007. Removal of Heavy Metal from Industrial Wastewater Using Modified Activated Coconut Shell Carbon. Biochem. Engi. J., 36: 174-181.

Guptaa, S., Babua, B.V. 2006. Adsorption of $\mathrm{Cr}(\mathrm{VI})$ by a Low-Cost Adsorbent Prepared from Neem Leaves. Proceeding of National Conference on Environmental Conservation, Pilani, 175-180.

Hashem, M.A. 2007. Adsorption of Lead Ion from Aqueous Solution by Okra Wastes. Int. J. Physical Sci., 2: 178184.

Liu, X., Q., Hu, Z., Fang, X., Zhang, Zhang, B. 2008. Magnetic chitosan nanocomposites: a useful recyclable tool for heavy metal ion removal. Langmuir, 25(3e): 8. 
Molinari, R., T. Poerio, R. Cassano, N. Picci, Argurio, P. 2004. Copper (II) removal from wastewaters by a new synthesized selective extractant and SLM viability. Ind. Eng. Chem. Res., 43(2): 623-628.

Moradi, O., Zare, K. 2011. Adsorption of Pb (II), $\mathrm{Cd}$ (II) and $\mathrm{Cu}$ (II) ions in aqueous solutionon SWCNTs and SWCNT_COOH surfaces: kinetics studies. Fullerenes Nanotubes Carbon Nanostruct, 19(7): 628-652.

Moradi, O., K. Zare, M. Monajjemi, M. Yari, Aghaie, H. 2010. The studies of equilibrium and thermodynamic adsorption of $\mathrm{Pb}$ (II), $\mathrm{Cd}$ (II) and $\mathrm{Cu}$ (II) Ions from aqueous solution onto SWCNTs and SWCNT_COOH Surfaces. Fullerenes Nanotubes Carbon Nanostruct, 18(3): 285-302.

Ngomsik, A.F., A. Bee, J.M. Siaugue, D. Talbot, V. Cabuil, Cote, G. 2009. Co (II) removal by magnetic alginate beads containing Cyanex 272. J. Hazard Mater., 166: 1043 e9.

Qadeer, R., Akhtar, S. 2005. Study of Lead Ion Adsorption of Active Carbon. Turkish J. Chem., 29: 95-99.

Shin, E.W., Rowell, R.M. 2005. Cadmium Ion Sorption onto Lignocellulosic Biosorbent Modified by Sulfonation: The Origin of Sorption Capacity Improvement. Chemosphere, 60: 1054-1061.

Vilar, V.J.P., C.M.S., Botelho, Boaventura, R.A.R. 2007. Copper desorption from Gelidium algal biomass. Water Res., 41: 1569-1579.

Yin, P., Q., Xu, R., Qu, G., Zhao, Sun, Y. 2010. Adsorption of transition metal ions from aqueous solutions onto a novel silica gel matrix inorganicorganic composite material. J. Hazard Mater., 173: 710 e6.

\section{How to cite this article:}

Ahmad Ashfaq and Mohd Kaifiyan. 2016. Application of Flyash for the Removal of Toxic Metals from Wastewaters through Biosorption. Int.J.Curr.Microbiol.App.Sci. 5(7): 121-125. doi: http://dx.doi.org/10.20546/ijcmas.2016.507.010 